\title{
Performance of the high-sensitivity troponin assay in diagnosing acute myocardial infarction: systematic review and meta-analysis
}

\author{
Ayman Al-Saleh MD, Ashraf Alazzoni MD, Saleh Al Shalash MD, Chenglin Ye MSc, \\ Lawrence Mbuagbaw MD MPH, Lehana Thabane PhD, Sanjit S. Jolly MD MSc
}

Abstract

Background: High-sensitivity cardiac troponin assays have been adopted by many clinical centres worldwide; however, clinicians are uncertain how to interpret the results. We sought to assess the utility of these assays in diagnosing acute myocardial infarction (MI).

Methods: We carried out a systematic review and meta-analysis of studies comparing high-sensitivity with conventional assays of cardiac troponin levels among adults with suspected acute MI in the emergency department. We searched MEDLINE, EMBASE and Cochrane databases up to April 2013 and used bivariable random-effects modelling to obtain summary parameters for diagnostic accuracy.

Results: We identified 9 studies that assessed the use of high-sensitivity troponin T assays ( $n=9186$ patients). The summary sensitivity of these tests in diagnosing acute $\mathrm{Ml}$ at presentation to the emergency department was estimated to be 0.94 (95\% confidence interval [Cl] 0.89-0.97); for conventional tests, it was $0.72(95 \% \mathrm{Cl} 0.63-0.79)$. The summary specificity was $0.73(95 \% \mathrm{Cl}$ 0.64-0.81) for the high-sensitivity assay compared with $0.95(95 \% \mathrm{Cl} 0.93-0.97)$ for the conventional assay. The differences in estimates of the summary sensitivity and specificity between the high-sensitivity and conventional assays were statistically significant $(p<0.01)$. The area under the curve was similar for both tests carried out 3-6 hours after presentation. Three studies assessed the use of high-sensitivity troponin I assays and showed similar results.

Interpretation: Used at presentation to the emergency department, the high-sensitivity cardiac troponin assay has improved sensitivity, but reduced specificity, compared with the conventional troponin assay. With repeated measurements over 6 hours, the area under the curve is similar for both tests, indicating that the major advantage of the high-sensitivity test is early diagnosis.

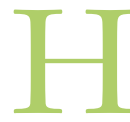
igh-sensitivity troponin assays have greatly improved the analytical performance of conventional cardiac troponin $\mathrm{T}$ and I testing. ${ }^{1-3}$ These assays permit the measurement of cardiac troponin concentrations that are about one-tenth of those measurable with conventional assays. ${ }^{4}$ The detection level is close to the physiologic concentrations of these biomarkers; ${ }^{5}$ therefore, there is interest in using high-sensitivity assays to diagnose acute myocardial infarction (MI) accurately, possibly within 3 hours of admission. The ability to use the rate of change in troponin level to diagnose acute $\mathrm{MI}$ is also being investigated. Many institutions throughout Europe and North America have transitioned from using the conventional troponin $\mathrm{T}$ assay to the high-sensitivity troponin $\mathrm{T}$ assay with no technical issues; both assays are run using the same analyzer. ${ }^{6}$ However, the US Food and Drug Administration has yet to approve the use of the high-sensitivity assays. This is partly because of the need for more information about their diagnostic accuracy and risk stratification. ${ }^{7}$

One of the main challenges is the potential for overdiagnosis of acute coronary syndromes because of the increased sensitivity of the high-sensitivity troponin test. Our aim was to assess the use of this test as a diagnostic tool. The early and accurate detection of myocardial injury leads to potentially earlier diagnosis

Competing interests: None declared.

This article has been peer reviewed.

Correspondence to: Ashraf Alazzoni, alazz_ash@hotmail.com CMAJ Open 2014.DOI:10.9778/cmajo.20130074 
and treatment with effective antiplatelet and antithrombotic agents. Use of the high-sensitivity troponin assay expedites exclusion of myocardial injury in patients presenting to the emergency department with chest pain. However, an assay that is very sensitive but has low specificity may lead to unnecessary investigations. We aimed to conduct a systematic review of the literature and a meta-analysis comparing the sensitivity, specificity and summary receiver operating characteristic curves of high-sensitivity troponin assays with those of conventional troponin $T$ and $I$ assays and test for heterogeneity.

\section{Methods}

\section{Search strategy}

A comprehensive systematic search of MEDLINE (1946 to April 2013), EMBASE (1980 to April 2013) and the Cochrane Central Register of Controlled Trials was carried out to find studies that compared high-sensitivity testing with conventional troponin $\mathrm{T}$ or I assays and included patients presenting to the emergency department with chest pain and suspected acute MI. Studies were excluded if they were case reports; evaluated high-sensitivity troponin assay in patients with heart failure; or were mainly designed to assess the prognostic impact of high-sensitivity troponin assay. Studies were also excluded if they did not directly compare high-sensitivity with conventional troponin testing. We restricted our search to studies published in English, and we manually searched abstracts from American Heart Association, American College of Cardiology and European Society of Cardiology conferences for the past 2 years. The indexed search terms we used were: highly sensitive troponin, high sensitivity troponin, high sensitive troponin, hs-TnT, hs-cTnT and hs-TnI. References listed in relevant articles were also reviewed for possible inclusion. Details of our search strategy are described in Appendix 1 (www.cmajopen.ca/content/2/3/E199/supp1/DC1).

Titles and abstracts were screened independently by 2 authors (A. Al-Saleh and A. Alazzoni) to ensure that they met the inclusion criteria (Figure 1). Agreement was estimated using the kappa statistic $(\kappa=0.80,95 \%$ CI $0.59-1.00$, $p<0.001$ indicating substantial agreement according to Koch and Landis ${ }^{18,19}$ ). Full texts of the selected articles were then screened by both authors for inclusion in the review. All disagreements were resolved by consensus.

\section{Risk of bias assessment}

Assessment of risk of bias was performed using the Cochrane tool: Quality Assessment of Diagnostic Accuracy Studies (QUADAS). ${ }^{8}$ This tool encompasses the following criteria, which we followed: representative spectrum, acceptable reference standard, acceptable delay between tests, partial verification avoided, differential verification avoided, incorporation avoided, reference standard results blinded, index test results blinded, uninterpretable results reported, withdrawals explained and sponsoring precluded.

\section{Statistical analysis}

In reporting our results, we followed the preferred reporting items for systematic reviews and meta-analyses (PRISMA) criteria. ${ }^{18}$ The process we used to select studies is summarized in a flowchart (Figure 1). We calculated sensitivity and specificity from the extracted contingency tables and individual study estimates were plotted in receiver operating characteristic curves. Heterogeneity was quantified using the $I^{2}$ test, calculated using the random-effect approach and expressed as a percentage of the total variation across studies that was thought to be due to heterogeneity and could not be explained by our model. The higher the percentage, the more heterogeneity. ${ }^{19,20}$ To obtain estimates of sensitivity and specificity, with corresponding $95 \%$ confidence intervals (CI), we used a bivariable random-effects model. ${ }^{21}$ Summary receiver operating characteristic curves were drawn, plotting individual studies as well as the summary estimate. We also conducted a head-to-head comparison of the sensitive and conventional tests in terms of the summary estimates of sensitivity and specificity using the bivariable random-effects model. A modified paired $z$-test ${ }^{22}$ was used to compare the mean logit sensitivity and logit specificity of the high-sensitivity and conventional troponin $\mathrm{T}$ assays at presentation. The statistical software used for this analysis was R, version 2.12.1.

\section{Results}

The literature review yielded 1035 articles from MEDLINE and EMBASE and 88 articles from the Cochrane database. After screening and applying the inclusion and exclusion criteria, 50 articles were isolated. After further review of the 50 articles, we excluded 17 articles not directly comparing the high-sensitivity and conventional tests, 13 that assessed a different population, such as patients with heart failure and 8 reviews and editorials (Figure 1). The remaining 11 studies were included in our meta-analysis. The selected studies were published between 2009 and 2012. The 38 excluded articles are listed in Appendix 2 (www.cmajopen.ca/content/2/3 /E199/suppl/DC1).

\section{Study populations and definition of outcomes}

The selected studies enrolled patients who presented to the emergency department with symptoms, such as chest pain, that were suggestive of acute MI. Patients underwent the usual initial clinical assessment that included history taking, physical examination and 12-lead electrocardiogram. Cardiac troponin level was measured at presentation and again 2-24 hours later. High-sensitivity assays were used to measure troponin $\mathrm{T}$ at presentation in 9 studies $^{9-17}$ (Table 1) and troponin I in 3 studies. ${ }^{9,23,24}$ The final diagnosis for each patient was determined by event adjudicators after they had reviewed all available medical records from the time of the patient's arrival in the emergency department to the end of the follow-up period (Table 1).

Acute MI was defined in accordance with the 2007 ESC/ ACCF/AHA guidelines ${ }^{25}$ in 9 studies. ${ }^{9-15,23,24}$ In brief, acute MI was diagnosed when the patient showed typical clinical signs of myocardial ischemia and evidence of myocardial necrosis. Myocardial necrosis was diagnosed on the basis of a rising or falling cardiac troponin pattern $(>20 \%$ or $<20 \%$ 
compared with level at admission) with at least 1 value above the 99th percentile and an imprecision of $\leq 10 \%$. Similar but earlier 2000 and 2001 American College of Cardiology guidelines were used in 2 studies. ${ }^{16,17}$

\section{Methodologic quality of the selected studies}

The QUADAS tool showed that the studies were generally of high quality (Table 2). All studies used an acceptable reference standard test and delays between tests were appropriate. A second or third reference standard was not used to verify diagnosis; thus, partial and differential verification bias was avoided in all studies. Most of the studies addressed the target population. Incorporation bias was not present in any of the studies, as high-sensitivity troponin assay was not incorporated in a composite reference standard. Blinding of reference standard results was unclear in 5 studies and blinding of the index test results was unclear in only 1 study. Explanation of withdrawals was unclear in 1 study.
Sponsoring was adequately precluded in 3 studies, but this remained unclear in 4.

\section{Sensitivity and specificity of the high-sensitivity troponin $\mathrm{T}$ assay}

\section{At presentation}

Based on data from the 9 studies $^{9-17}$ that used the highsensitivity troponin $\mathrm{T}$ assay (cut-off point $14 \mathrm{ng} / \mathrm{L}$ ) at presentation to the emergency department (Table 3 and Figure 2), the summary sensitivity was estimated to be $0.93(95 \% \mathrm{CI}$ $0.89-0.96)$ and the heterogeneity $\left(I^{2}\right)$ was $32.53 \%$ (95\% CI $0.00 \%-68.88 \%)$. The summary specificity for the assay was estimated to be 0.74 (95\% CI $0.66-0.81)$ and $I^{2}$ was $32.35 \%$ (95\% CI $0.00 \%-68.79 \%$ ).

Only 8 studies ${ }^{10-17}$ reported sensitivity and specificity for both the high-sensitivity troponin $\mathrm{T}$ assay and the conventional troponin $\mathrm{T}$ or I assay, allowing us to conduct a head-to-

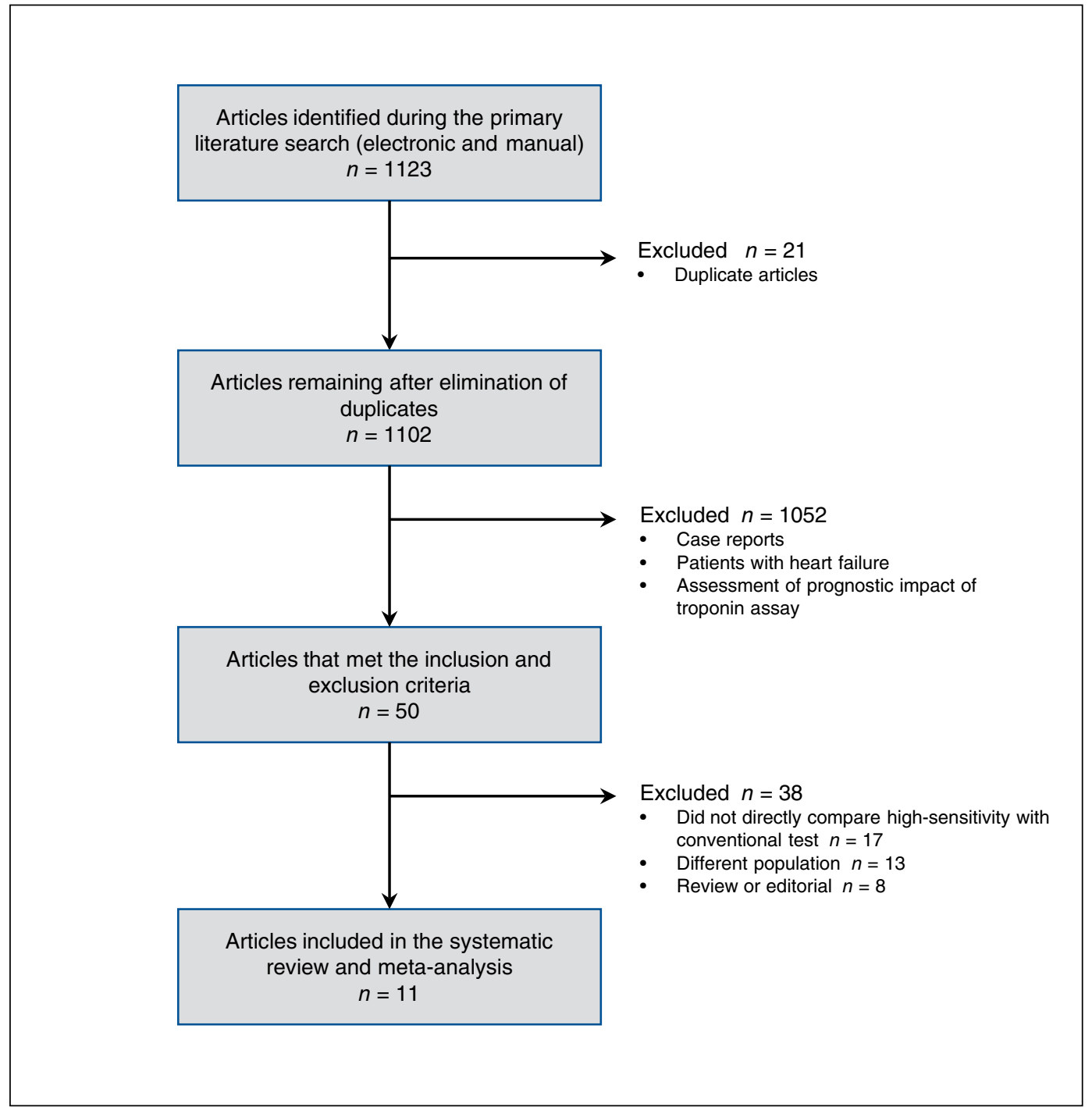

Figure 1: Identification of studies comparing high-sensitivity testing with conventional testing of cardiac troponin levels to diagnose myocardial infarction in the emergency department. 


\section{OPEN}

Table 1: Characteristics of the studies that compared the high-sensitivity troponin T assay or high-sensitivity troponin I assay with the conventional assay

\begin{tabular}{|c|c|c|c|c|c|c|c|}
\hline Study & $\begin{array}{l}\text { Participants, } \\
\text { no. (\% male) }\end{array}$ & Funding & Design & Centre(s) & $\begin{array}{l}\text { Timing of } \\
\text { troponin } \\
\text { measurement }\end{array}$ & $\begin{array}{l}\text { Outcome, } \\
\text { no. (\%) }\end{array}$ & $\begin{array}{l}\text { Follow-up } \\
\text { period }\end{array}$ \\
\hline \multicolumn{8}{|l|}{ Troponin T } \\
\hline $\begin{array}{l}\text { Reichlin } \\
\text { et al. } 2009^{9}\end{array}$ & $718(66)$ & $\begin{array}{l}\text { Swiss Heart Foundation, } \\
\text { University Hospital, Basel, } \\
\text { Abbott, Roche, Siemens }\end{array}$ & Prospective & $\begin{array}{l}\text { Multicentre: } \\
\text { Switzerland, } \\
\text { Italy and } \\
\text { Spain }\end{array}$ & $\begin{array}{l}\text { At presentation } \\
\text { and 6-9 h later }\end{array}$ & $\begin{array}{c}\mathrm{Ml} \\
123(17)\end{array}$ & $60 \mathrm{~d}$ \\
\hline $\begin{array}{l}\text { Christ } \\
\text { et al. } 2010^{10}\end{array}$ & $2340(64)$ & Roche Diagnostics & Retrospective & $\begin{array}{l}\text { Single centre: } \\
\text { Germany }\end{array}$ & $\begin{array}{l}\text { At presentation } \\
\text { and about } 6 \mathrm{~h} \text { later }\end{array}$ & $\begin{array}{c}\mathrm{Ml} \\
20(15)\end{array}$ & $2 w k$ \\
\hline $\begin{array}{l}\text { Aldous } \\
\text { et al. } 2011^{11}\end{array}$ & $332(60)$ & $\begin{array}{l}\text { National Heart Foundation } \\
\text { of New Zealand, } \\
\text { Christchurch Hospital, } \\
\text { Roche Diagnostics }\end{array}$ & Prospective & $\begin{array}{l}\text { Single centre: } \\
\text { New Zealand }\end{array}$ & $\begin{array}{l}\text { At presentation } \\
\text { and } 6-24 \mathrm{~h} \text { later }\end{array}$ & $\begin{array}{c}\mathrm{Ml} \\
110(33)\end{array}$ & $\begin{array}{l}\text { Not } \\
\text { reported }\end{array}$ \\
\hline $\begin{array}{l}\text { Body } \\
\text { et al. } 2011^{12}\end{array}$ & $703(61)$ & $\begin{array}{l}\text { Manchester NHS } \\
\text { Foundation Trust, Roche } \\
\text { Diagnostics }\end{array}$ & Prospective & $\begin{array}{l}\text { Single centre: } \\
\text { United } \\
\text { Kingdom }\end{array}$ & $\begin{array}{l}\text { At presentation } \\
\text { and (at least) } 12 \mathrm{~h} \\
\text { after onset of } \\
\text { symptoms }\end{array}$ & $\begin{array}{c}\mathrm{Ml} \\
130(18)\end{array}$ & $6 \mathrm{mo}$ \\
\hline $\begin{array}{l}\text { Freund } \\
\text { et al. } 2011^{13}\end{array}$ & $317(65)$ & $\begin{array}{l}\text { Université Pierre et Marie } \\
\text { Curie-Paris } 6, \text { Roche } \\
\text { Diagnostics }\end{array}$ & Prospective & $\begin{array}{l}3 \text { centres: } \\
\text { France }\end{array}$ & $\begin{array}{l}\text { At presentation } \\
\text { and } 3-9 \mathrm{~h} \text { later (if } \\
\text { clinically indicated) }\end{array}$ & $\begin{array}{c}\mathrm{Ml} \\
45(14)\end{array}$ & $30 \mathrm{~d}$ \\
\hline $\begin{array}{l}\text { Melki } \\
\text { et al. } 2011^{14}\end{array}$ & $233(67)$ & $\begin{array}{l}\text { Stockholm County Council } \\
\text { and Karolinska Institute, } \\
\text { Swedish Heart and Lung } \\
\text { Foundation, National Board } \\
\text { of Health and Welfare, } \\
\text { Roche Diagnostics }\end{array}$ & Prospective & $\begin{array}{l}\text { Single centre: } \\
\text { Sweden }\end{array}$ & $\begin{array}{l}\text { At presentation } \\
\text { and } 9-12 \mathrm{~h} \text { later }\end{array}$ & $\begin{array}{c}\mathrm{Ml} \\
114(48)\end{array}$ & $\begin{array}{l}\text { Discharge } \\
\text { from } \\
\text { hospital }\end{array}$ \\
\hline $\begin{array}{l}\text { Reiter } \\
\text { et al. } 2011^{15}\end{array}$ & $1098(67)^{*}$ & $\begin{array}{l}\text { Swiss Heart Foundation, } \\
\text { University Hospital, Basel, } \\
\text { Abbott, Roche, Siemens }\end{array}$ & Prospective & $\begin{array}{l}\text { Multicentre: } \\
\text { Switzerland, } \\
\text { Italy and } \\
\text { Spain }\end{array}$ & $\begin{array}{l}\text { At presentation } \\
\text { and 6-9 h later }\end{array}$ & $\begin{array}{c}\text { MI } \\
159(14)\end{array}$ & $90 \mathrm{~d}$ \\
\hline $\begin{array}{l}\text { Weber } \\
\text { et al. } 2011^{16}\end{array}$ & $2506(66)$ & $\begin{array}{l}\text { Kerckhoff-Stiftung } \\
\text { Foundation, Sanofi Aventis, } \\
\text { Roche Diagnostics }\end{array}$ & $\begin{array}{l}\text { Retrospective } \\
\text { analysis of data } \\
\text { from } 2 \text { acute } \\
\text { coronary syndrome } \\
\text { registries }\end{array}$ & $\begin{array}{l}\text { Multicentre: } \\
\text { Germany and } \\
\text { Argentina }\end{array}$ & At presentation & $\begin{array}{c}\mathrm{MI} \\
1082 \\
(43)\end{array}$ & $6 \mathrm{mo}$ \\
\hline $\begin{array}{l}\text { Aldous } \\
\text { et al. } 2012^{17}\end{array}$ & $939(59)$ & $\begin{array}{l}\text { National Heart Foundation } \\
\text { of New Zealand, Health } \\
\text { Research Council of New } \\
\text { Zealand, Roche Diagnostics }\end{array}$ & Prospective & $\begin{array}{l}\text { Multicentre: } \\
9 \text { countries in } \\
\text { the Asia- } \\
\text { Pacific region }\end{array}$ & $\begin{array}{l}\text { At presentation, } \\
2 \mathrm{~h} \text { and } 6-12 \mathrm{~h} \\
\text { later }\end{array}$ & $\begin{array}{c}\mathrm{Ml} \\
205(21)\end{array}$ & $1 \mathrm{yr}$ \\
\hline \multicolumn{8}{|l|}{ Troponin I } \\
\hline $\begin{array}{l}\text { Reichlin } \\
\text { et al. } 2009^{9}\end{array}$ & $718(66)$ & $\begin{array}{l}\text { Swiss Heart Foundation, } \\
\text { University Hospital, Basel, } \\
\text { Abbott, Roche, Siemens }\end{array}$ & Prospective & $\begin{array}{l}\text { Multicentre: } \\
\text { Switzerland, } \\
\text { Italy and } \\
\text { Spain }\end{array}$ & $\begin{array}{l}\text { At presentation } \\
\text { and 6-9 h later }\end{array}$ & $\begin{array}{c}\mathrm{Ml} \\
123(17)\end{array}$ & $60 \mathrm{~d}$ \\
\hline $\begin{array}{l}\text { Keller } \\
\text { et al. } 2009^{24}\end{array}$ & $1818(66)$ & Not available & Prospective & $\begin{array}{l}\text { Multicentre: } \\
\text { Germany }\end{array}$ & $\begin{array}{l}\text { At presentation } \\
\text { and 3-6 h later }\end{array}$ & $\begin{array}{c}\mathrm{Ml} \\
413(23)\end{array}$ & $30 \mathrm{~d}$ \\
\hline $\begin{array}{l}\text { Bhardwaj } \\
\text { et al. } 2011^{23}\end{array}$ & $318(54)$ & $\begin{array}{l}\text { Inverness Medical } \\
\text { Innovations }\end{array}$ & Prospective & $\begin{array}{l}\text { Multicentre: } \\
\text { United States }\end{array}$ & $\begin{array}{l}\text { At presentation } \\
\text { and repeated if } \\
\text { clinically indicated }\end{array}$ & $\begin{array}{c}\text { ACS } \\
62(20)\end{array}$ & $30 d$ \\
\hline
\end{tabular}


head comparison. Summary sensitivities were estimated to be 0.94 (95\% CI 0.89-0.97) and 0.72 (95\% CI 0.63-0.79) for the high-sensitivity troponin $\mathrm{T}$ assay and the conventional assay, respectively. The summary specificities were estimated to be 0.73 (95\% CI 0.64-0.81) and 0.95 (95\% CI 0.93-0.97), respectively. The differences between the high-sensitivity and conventional assays in terms of both summary sensitivity and specificity were statistically significant $(p<0.01)$.

The summary receiver operating characteristic curve shows that the $95 \%$ confidence region of the pair of summary measures estimated from the high-sensitivity troponin $\mathrm{T}$ test did not overlap with that estimated from the conventional troponin assay (Figure 3). Thus, these results suggest that the high-sensitivity troponin $\mathrm{T}$ test has significantly higher sensitivity, whereas the conventional test has significantly higher specificity.

\section{Serial troponin measurement}

Only two ${ }^{9,15}$ of the selected studies presented area under the curve levels for high-sensitivity troponin $\mathrm{T}$ assays 3 and 6 hours after presentation in the emergency department (Table 4). Reichlin and colleagues ${ }^{9}$ reported similar areas under the curve for high-sensitivity troponin $\mathrm{T}$ assays and conventional troponin assays at 3 and 6 hours. For the highsensitivity test, area under the curve was 0.98 (95\% CI $0.97-$ $0.99)$ at 3 hours and 0.98 (95\% CI 0.96-0.99) at 6 hours; for the conventional troponin assay, area under the curve was 0.97 (95\% CI 0.94-1.00) at 3 hours and 0.98 (95\% CI $0.96-$ $0.99)$ at 6 hours. Reiter and associates ${ }^{15}$ reported similar results: for high-sensitivity troponin $\mathrm{T}$ assay, area under the curve was 0.97 (95\% CI 0.94-0.99) at 3 hours and 0.96 (95\% CI 0.92-0.99) at 6 hours; for conventional troponin assays, the area under the curve was 0.97 (95\% CI $0.93-0.99)$ at 3 hours and 0.97 (95\% CI $0.92-0.99)$ at 6 hours. In summary, given repeated measures over 6 hours from presentation, the areas under the curves for high-sensitivity troponin $\mathrm{T}$ and conventional troponin assays were similar.

\section{Sensitivity and specificity of the high-sensitivity troponin I assay}

Different assays and cut-off points have been used for studies of high-sensitivity troponin I assays (Table 5). ${ }^{9,23,24}$ Using an ADVIA Centaur immunoassay system (Siemens, Erlangen, Germany) to test for troponin I (cut-off point $40 \mathrm{ng} / \mathrm{L}$ ), Reichlin and colleagues ${ }^{9}$ found the sensitivity and specificity to be 0.89 and 0.92 compared with 0.72 and 0.97 , respectively, for the conventional assay. The Architect assay (Abbott Laboratories, Abbott Park, Ill.; cut-off point $28 \mathrm{ng} / \mathrm{L}$ ) yielded a sensitivity of 0.86 and a specificity of 0.92 ; the Roche Troponin I assay (Roche, Basel, Switzerland; cut-off point $160 \mathrm{ng} / \mathrm{L}$ ) yielded a sensitivity of 0.84 and a specificity of 0.94 . On the other hand, using an Erenna Immunoassay System (Singulex,

Table 2: Assessment of the studies that tested the high-sensitivity troponin T assay or high-sensitivity troponin I assay for risk of bias using the Quality Assessment of Diagnostic Accuracy Studies tool ${ }^{8}$

Study

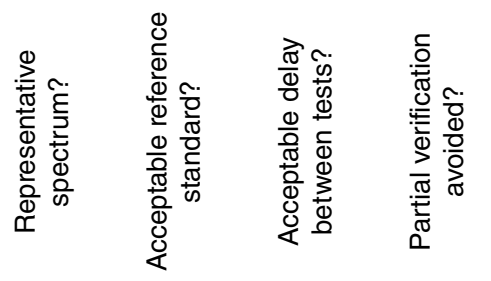
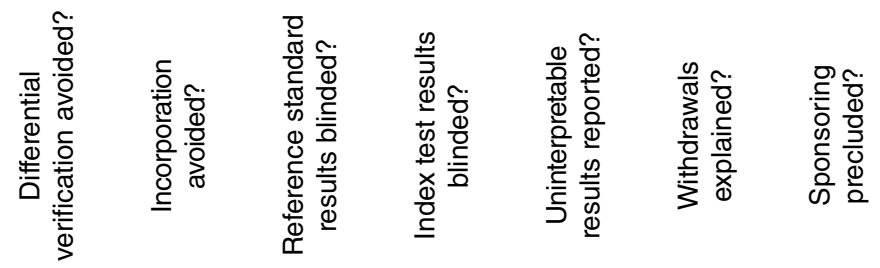

Troponin T

\begin{tabular}{|c|c|c|c|c|c|c|c|c|c|c|c|}
\hline Reichlin et al. $2009^{9}$ & Yes & Yes & Yes & Yes & Yes & Yes & Yes & Yes & No & Yes & Yes \\
\hline Christ et al. $2010^{10}$ & Yes & Yes & Yes & Yes & Yes & Yes & Unclear & Unclear & Yes & Yes & Yes \\
\hline Aldous et al. $2011^{11}$ & No & Yes & Yes & Yes & Yes & Yes & No & Yes & Yes & Yes & Yes \\
\hline Body et al. $2011^{12}$ & Yes & Yes & Yes & Yes & Yes & Yes & Unclear & Yes & Yes & Yes & No \\
\hline Freund et al. $2011^{13}$ & Yes & Yes & Yes & Yes & Yes & Yes & Unclear & Yes & Yes & Yes & Unclear \\
\hline Melki et al. $2011^{14}$ & Yes & Yes & Yes & Yes & Yes & Yes & Yes & Yes & Yes & Yes & Unclear \\
\hline Reiter et al. $2011^{15}$ & Yes & Yes & Yes & Yes & Yes & Yes & Yes & Yes & Yes & Yes & Yes \\
\hline Weber et al. $2011^{16}$ & Yes & Yes & Yes & Yes & Yes & Yes & Unclear & Yes & Yes & Unclear & Unclear \\
\hline Aldous et al. $2012^{17}$ & Yes & Yes & Yes & Yes & Yes & Yes & Unclear & Yes & Yes & Yes & Unclear \\
\hline
\end{tabular}

Troponin I

$\begin{array}{lcccccccccccc}\text { Reichlin et al. 20099 } & \text { Yes } & \text { Yes } & \text { Yes } & \text { Yes } & \text { Yes } & \text { Yes } & \text { Yes } & \text { Yes } & \text { No } & \text { Yes } & \text { Yes } \\ \text { Keller et al. } 2009^{24} & \text { Yes } & \text { Yes } & \text { Yes } & \text { Yes } & \text { Yes } & \text { Yes } & \text { Unclear } & \text { Yes } & \text { Yes } & \text { Yes } & \text { Unclear } \\ \text { Bhardwaj et al. } 2011^{23} & \text { Yes } & \text { Yes } & \text { Unclear } & \text { Yes } & \text { Yes } & \text { Yes } & \text { Unclear } & \text { Yes } & \text { Yes } & \text { Yes } & \text { Yes }\end{array}$

Note: Yes = high quality, No = low quality

Weighted $\kappa=0.70,95 \%$ confidence interval $0.54-0.87, p<0.001$ (indicates substantial agreement according to Koch and Landis). ${ }^{18,19}$ 


\section{OPEN}

Alameda, Cal.; cut-off point $6.28 \mathrm{ng} / \mathrm{L})$, Bhardwaj and colleagues ${ }^{23}$ reported a sensitivity of 0.57 and a specificity of 0.86 compared with 0.22 and 0.97 , respectively, for the conventional assay. Given the heterogeneous findings of different high-sensitivity troponin I assays, it is not possible to combine the results. It appears that the Architect (Abbott) and ADVIA Centaur (Siemens) high-sensitivity troponin I assays have lower sensitivity but improved specificity compared with high-sensitivity troponin $\mathrm{T}$ assays.

\section{Interpretation}

Our meta-analysis shows that the use of the high-sensitivity troponin assay to diagnose acute MI at presentation to the emergency department resulted in a significantly higher sensitivity compared with the conventional assay, although with reduced specificity. However, the areas under the receiver operating characteristic curves (an effective way to summarize the overall accuracy of diagnostic tests) for repeated measurements over 6 hours were similar for the 2 tests. Thus, the major advantage of the high-sensitivity troponin assay is early diagnosis and treatment of non-ST elevation MI.

The heterogeneity in our meta-analysis was in the low to moderate range: $I^{2}$ was $32.53 \%$ for sensitivity and $32.35 \%$ for specificity. ${ }^{19,20}$ This is explained by the use of different conventional troponin assays with different cut-off values as comparators.

\section{Explanation and comparison with other studies}

This review and meta-analysis comparing sensitivity and specificity of the high-sensitivity troponin assay with standard troponin assays among patients presenting with chest pain is important to clinicians whose institution adopts the highsensitivity troponin assay. A prognosis-based systematic review of the high-sensitivity assay ${ }^{26}$ showed that, among patients presenting with chest pain who had a negative con-

Table 3: Diagnostic performance of high-sensitivity troponin T versus conventional troponin assay at presentation.

\begin{tabular}{|c|c|c|c|c|c|c|c|c|c|c|}
\hline \multirow[b]{2}{*}{ Study } & \multicolumn{5}{|c|}{ High-sensitivity troponin T assay } & \multicolumn{5}{|c|}{ Conventional troponin assay } \\
\hline & Assay & Sensitivity & Specificity & NPV, \% & PPV, \% & Cut-off point and assay & Sensitivity & Specificity & NPV, \% & PPV, \% \\
\hline $\begin{array}{l}\text { Reichlin } \\
\text { et al. } 2009^{9}\end{array}$ & $\begin{array}{l}\text { Elecsys } 2010 \\
\text { (Roche } \\
\text { Diagnostics) }\end{array}$ & 0.95 & 0.80 & 99 & 50 & $\begin{array}{l}\text { Troponin T, } 0.035 \mathrm{ng} / \\
\mathrm{mL} \text { (4th generation, } \\
\text { Roche) }\end{array}$ & 0.72 & 0.97 & 94 & 85 \\
\hline $\begin{array}{l}\text { Christ } \\
\text { et al. } 2010^{10}\end{array}$ & $\begin{array}{l}\text { Elecsys } 2010 \\
\text { (Roche } \\
\text { Diagnostics) }\end{array}$ & 0.95 & 0.62 & 98.6 & 29.7 & $\begin{array}{l}\text { Troponin } \mathrm{T}, 0.04 \mathrm{ng} / \mathrm{mL} \\
\text { (4th generation, Roche } \\
\text { Diagnostics) }\end{array}$ & 0.65 & 0.91 & 93.8 & 54.2 \\
\hline $\begin{array}{l}\text { Aldous } \\
\text { et al. } 2011^{11}\end{array}$ & $\begin{array}{l}\text { Elecsys (Roche } \\
\text { Diagnostics) }\end{array}$ & 0.84 & 0.84 & 91.2 & 71.9 & $\begin{array}{l}\text { Troponin T, } 0.03 \mathrm{ng} / \mathrm{mL} \\
\text { (Elecsys 2010, Roche } \\
\text { Diagnostics) }\end{array}$ & 0.43 & 0.97 & 77.4 & 88.7 \\
\hline $\begin{array}{l}\text { Body } \\
\text { et al. } 2011^{12}\end{array}$ & Roche & 0.85 & 0.82 & 96.1 & 52.4 & $\begin{array}{l}\text { Troponin T, } 0.01 \mathrm{ng} / \mathrm{mL} \\
\text { (4th generation) }\end{array}$ & 0.75 & 0.95 & 94.4 & 75.8 \\
\hline $\begin{array}{l}\text { Freund } \\
\text { et al. } 2011^{13}\end{array}$ & $\begin{array}{l}\text { Elecsys } 2010 \\
\text { (Roche } \\
\text { Diagnostics) }\end{array}$ & 0.93 & 0.82 & 99 & 47 & $\begin{array}{l}\text { Troponin I, } 0.06 \mathrm{ng} / \mathrm{mL} \\
\text { (Access analyzer, } \\
\text { Beckman Coulter) or } \\
\text { Troponin I, } 0.14 \mathrm{ng} / \mathrm{mL} \\
\text { (Xpand HM analyzer, } \\
\text { Siemens Healthcare } \\
\text { Diagnostics) }\end{array}$ & 0.71 & 0.97 & 95 & 78 \\
\hline $\begin{array}{l}\text { Melki } \\
\text { et al. } 2011^{14}\end{array}$ & $\begin{array}{l}\text { Roche } \\
\text { Diagnostics }\end{array}$ & 0.97 & 0.74 & 97 & 78 & $\begin{array}{l}\text { Troponin T, } 0.04 \mathrm{ng} / \mathrm{mL} \\
\text { (4th generation, Roche } \\
\text { Diagnostics) }\end{array}$ & 0.79 & 0.94 & 82 & 93 \\
\hline $\begin{array}{l}\text { Reiter } \\
\text { et al. } 2011^{15}\end{array}$ & $\begin{array}{l}\text { Elecsys } 2010 \\
\text { (Roche } \\
\text { Diagnostics) }\end{array}$ & 0.98 & 0.49 & 99 & 38 & $\begin{array}{l}\text { Troponin T, } 0.035 \mathrm{ng} / \\
\mathrm{mL} \text { (Roche) }\end{array}$ & 0.76 & 0.96 & 93 & 86 \\
\hline $\begin{array}{l}\text { Weber } \\
\text { et al. } 2011^{16}\end{array}$ & $\begin{array}{l}\text { Elecsys (Roche } \\
\text { Diagnostics) }\end{array}$ & 0.96 & 0.61 & 80 & 91 & $\begin{array}{l}\text { Troponin T, } 0.03 \mathrm{ng} / \mathrm{mL} \\
\text { (Elecsys, Roche } \\
\text { Diagnostics) }\end{array}$ & 0.82 & 0.90 & 54 & 97 \\
\hline $\begin{array}{l}\text { Aldous } \\
\text { et al. } 2012^{17}\end{array}$ & $\begin{array}{l}\text { Elecsys (Roche } \\
\text { Diagnostics) }\end{array}$ & 0.88 & 0.82 & 96.2 & 57.5 & $\begin{array}{l}\text { Troponin I, } 0.028 \mathrm{ng} / \\
\mathrm{mL} \text { (Architect system, } \\
\text { Abbott Diagnostics) }\end{array}$ & NA & NA & NA & NA \\
\hline
\end{tabular}


ventional assay but a positive high-sensitivity troponin assay, mortality was significantly higher than if both assays were negative. In that study, nearly a third of patients presenting with chest pain had a positive high-sensitivity troponin assay but a negative conventional assay. Although this suggests a higher rate of diagnosis of acute MI when the high-sensitivity assay was used instead of a conventional assay, this was associated with an adverse prognosis. Further data are needed to determine the effect of use of the high-sensitivity assay on outcomes and costs in the treatment of patients with suspected acute MI.

Another issue to consider is whether serial measurement of cardiac troponin level can enhance diagnosis of acute MI. This can involve measuring the high-sensitivity troponin at presentation to hospital and 1 or 2 hours later. Then diagnosis of acute MI might be made using initial result and amount of increase over the first couple of hours (relative to first result as a percentage or absolute change in troponin level). When the high-sensitivity troponin assay is used, large relative changes may occur despite minor absolute level increases, which is partly due to the ability of the sensitive troponin assay to detect troponin levels as low as the normal range. ${ }^{28}$ In a study of the absolute and relative changes in troponin levels at presentation and after 1 and 2 hours, absolute changes measured using the highsensitivity troponin $T$ assay had significantly greater diagnostic accuracy than relative changes. ${ }^{29}$ Despite the increased sensitivity of this assay at presentation, guideline committees have been reluctant to endorse its use to rule out acute MI based on a single value. In an investigation of an algorithm designed to expedite discharge of patients presenting to the emergency department with chest pain, acute MI was ruled out among patients with troponin $\mathrm{T}$ below

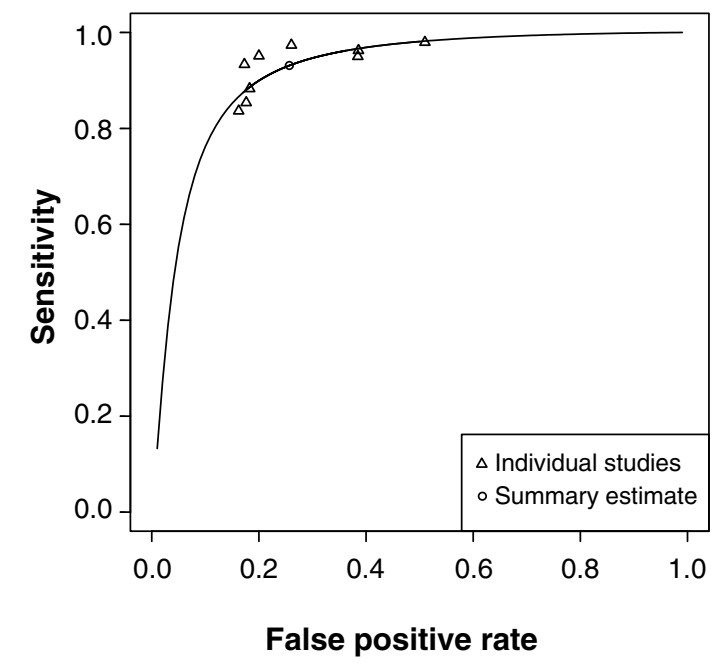

Figure 2: Summary receiver operating characteristic curve (bivariable model) for the high-sensitivity troponin $T$ assay for the diagnosis of acute myocardial infarction at presentation, based on meta-analysis of 9 studies.
$12 \mathrm{ng} / \mathrm{L}$ at presentation and a change of less than $3 \mathrm{ng} / \mathrm{L}$ over the first hour based on the sensitive assay. ${ }^{30}$ The sensitivity of this approach was $100 \%$ for the rule-out group, supporting the concept that it was safe enough to rule out acute MI. An algorithm, such as this, could reduce patients' time in the emergency department from 6-8 hours to 1-2 hours.

Finally, other advantages and disadvantages of using the high-sensitivity troponin assay in the emergency department must be considered. For example, early diagnosis of acute MI will allow earlier initiation of anticoagulant and antiplatelet therapy and, potentially, more efficient care. The assay may also improve triaging of patients presenting with chest pain. On the other hand, its lower specificity may result in prolonged hospital stays and the increased use of invasive tests, such as angiography, in patients with normal coronary arteries. Randomized trials comparing the systematic use of the high-sensitivity troponin assay versus the conventional assay in patients presenting with chest pain would be able to determine the potential benefit of early initiation of therapies in terms of clinical outcomes and time to safe discharge from the hospital.

\section{Limitations}

The multiple analyzers and various cut-off points associated with the high-sensitivity troponin I assay preclude attempts to meta-analyze the data because of significant heterogeneity. The variation in intervals between initial assay and retesting limited our ability to assess the diagnostic accuracy of the high-sensitivity troponin $\mathrm{T}$ assay at different times after symptom onset, except at presentation where data were

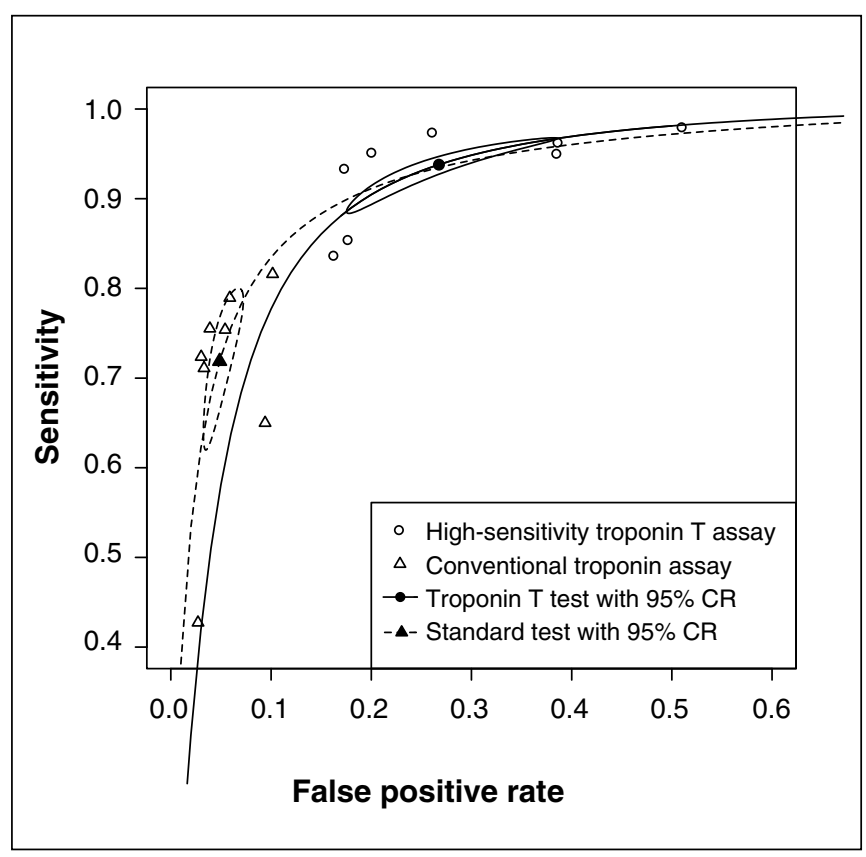

Figure 3: Comparison of receiver operating characteristic curves for the high-sensitivity troponin $\mathrm{T}$ assay and the conventional troponin assay for the diagnosis of acute myocardial infarction at presentation. The loops surrounding the filled shapes summarize the $95 \%$ confidence regions (CRs) for each test. 
available from all trials. Furthermore, the reference standard for acute $\mathrm{MI}$ adjudication was a conventional troponin assay, which will eventually underestimate the sensitivity and specificity of the high-sensitivity troponin $\mathrm{T}$ assay and overestimate them for the conventional troponin assay. The selected studies also used different conventional troponin assays and cut-off points as a reference standard for acute MI adjudication, and this may be a source of bias. Finally, only English-language studies were included in our analysis; relevant studies in other languages may have been omitted.

\begin{tabular}{|c|c|c|}
\hline \multirow[b]{2}{*}{ Study } & \multicolumn{2}{|c|}{ Diagnostic performance using serial high-sensitivity troponin $T$ assays } \\
\hline & Early assay, AUC (95\% Cl) & Later assay, AUC (95\% Cl) \\
\hline Reichlin et al. $2009^{9}$ & $\begin{array}{c}3 \mathrm{~h} \text { from presentation: } \\
0.98(0.97-0.99)\end{array}$ & $\begin{array}{c}6 \mathrm{~h} \text { from presentation: } \\
0.98(0.96-0.99)\end{array}$ \\
\hline Reiter et al. $2011^{* 15}$ & $\begin{array}{c}3 \mathrm{~h} \text { from presentation: } \\
0.97(0.94-0.99)\end{array}$ & $\begin{array}{c}6 \mathrm{~h} \text { from presentation: } \\
0.96(0.92-0.99)\end{array}$ \\
\hline Christ et al. $2010^{10}$ & NA & NA \\
\hline Aldous et al. $2011^{11}$ & NA & $\begin{array}{c}6-24 \mathrm{~h} \text { from presentation: } \\
0.94(0.91-0.97)\end{array}$ \\
\hline Body et al. $2011^{12}$ & NA & NA \\
\hline Freund et al. $2011^{13}$ & NA & NA \\
\hline Weber et al. $2011^{16}$ & NA & NA \\
\hline Melki et al. $2011^{14}$ & $\begin{array}{c}2 \text { h from presentation: } \\
\text { sensitivity } 0.99 \text {, specificity } 0.71 \\
\text { PPV } 77 \% \text {, NPV } 99 \%\end{array}$ & NA \\
\hline Aldous et al. $2012^{17}$ & $\begin{array}{l}2 \text { h from presentation: } \\
\text { sensitivity } 0.92 \text {, specificity } 0.80 \\
\text { PPV } 55.9 \% \text {, NPV } 97.3 \%\end{array}$ & NA \\
\hline \multicolumn{3}{|c|}{$\begin{array}{l}\text { Note: } \mathrm{AUC}=\text { area under the curve, } \mathrm{Cl}=\text { confidence interval, } \mathrm{NA}=\text { not available, } \mathrm{NPV}=\text { negative predictive value, } \mathrm{PPV} \\
=\text { positive predictive value. } \\
{ }^{*} \text { Older population }(\geq 70 \mathrm{yr}) .\end{array}$} \\
\hline
\end{tabular}

Table 5: Diagnostic performance of high-sensitivity troponin I versus conventional troponin T assay at presentation

\begin{tabular}{|c|c|c|c|c|c|c|c|c|c|c|}
\hline \multirow[b]{2}{*}{ Study } & \multicolumn{5}{|c|}{ High-sensitivity troponin I assay } & \multicolumn{5}{|c|}{ Conventional troponin $\mathrm{T}$ assay } \\
\hline & $\begin{array}{l}\text { Cut-off point } \\
\text { and assay }\end{array}$ & Sensitivity & Specificity & NPV, \% & PPV, \% & $\begin{array}{l}\text { Cut-off point } \\
\text { and assay }\end{array}$ & Sensitivity & Specificity & NPV, \% & PPV, \% \\
\hline $\begin{array}{l}\text { Reichlin } \\
\text { et al. } 2009^{9}\end{array}$ & $\begin{array}{l}40 \mathrm{ng} / \mathrm{L} \\
\text { ADVIA Centaur } \\
\text { Immunoassay } \\
\text { System } \\
\text { (Siemens) }\end{array}$ & 0.89 & 0.92 & 98 & 68 & $\begin{array}{l}0.035 \mathrm{ng} / \mathrm{mL} \\
\text { 4th generation } \\
\text { (Roche) }\end{array}$ & 0.72 & 0.97 & 94 & 85 \\
\hline $\begin{array}{l}\text { Bhardwaj } \\
\text { et al. } 2011^{23}\end{array}$ & $\begin{array}{l}6.28 \mathrm{ng} / \mathrm{L} \\
\text { Erenna } \\
\text { Immunoassay } \\
\text { System } \\
\text { (Singulex) }\end{array}$ & 0.57 & 0.86 & 89 & 50 & $\begin{array}{l}0.03 \mathrm{ng} / \mathrm{mL} \\
\text { Elecsys } 2010 \text { or } \\
\text { E170 platforms } \\
\text { (Roche } \\
\text { Diagnostics) }\end{array}$ & 0.22 & 0.97 & 84 & 65 \\
\hline $\begin{array}{l}\text { Keller } \\
\text { et al. } 2009^{24}\end{array}$ & $\begin{array}{l}40 \mathrm{ng} / \mathrm{L} \\
\text { Troponin I Ultra } \\
\text { (Siemens } \\
\text { Healthcare } \\
\text { Diagnostics) }\end{array}$ & 0.91 & 0.90 & 96.4 & 76.7 & $\begin{array}{l}0.03 \mathrm{ng} / \mathrm{mL} \\
\text { (Roche) }\end{array}$ & 0.64 & 0.97 & 88.3 & 88.8 \\
\hline
\end{tabular}




\section{Conclusion}

For patients presenting to the emergency department, the high-sensitivity assay for cardiac troponin has higher sensitivity but lower specificity than the conventional assay and, thus, may be useful in triaging patients. Over 6 hours, the area under the curve for both high-sensitivity troponin $\mathrm{T}$ and conventional troponin assays was similar. Future studies are needed to determine the potential benefits of earlier treatment and the economic consequences of the use of the highsensitivity assay.

\section{References}

1. Apple FS, Smith SW, Pearce LA, et al. Use of the centaur TnI-ultra assay for detection of myocardial infarction and adverse events in patients presenting with symptoms suggestive of acute coronary syndrome. Clin Chem 2008;54:723-8.

2. Casals G, Filella X, Augé JM, et al. Impact of ultrasensitive cardiac troponin I dynamic changes in the new universal definition of myocardial infarction. $\mathrm{Am}$ 7 Clin Pathol 2008;130:964-8.

3. Kavsak PA, MacRae AR, Yerna MJ, et al. Analytic and clinical utility of a next-generation, highly sensitive cardiac troponin I assay for early detection of myocardial injury. Clin Chem 2009;55:573-7.

4. Tate JR. Troponin revisited 2008: assay performance. Clin Chem Lab Med 2008;46:1489-500

5. Missov ED, De Marco T. Clinical insights on the use of highly sensitive cardiac troponin assays. Clin Chim Acta 1999;284:175-85.

6. Twerenbold R, Reichlin T, Reiter M, et al. High-sensitive cardiac troponin: Friend or foe? Swiss Med Wkly 2011;141:w13202.

7. Apple FS. High-sensitivity cardiac troponin for screening large populations of healthy people: is there risk? Clin Chem 2011;57:537-9.

8. Reitsma, JB, Rutjes, AWS, Whiting, P, et al. Chapter 9: Assessing methodological quality. In: Deeks JJ, Bossuyt PM, Gatsonis C. editors. Cochrane handbook for systematic reviews of diagnostic test accuracy Version 1.0.0. London (UK): Cochrane Collaboration; 2009.

9. Reichlin T, Hochholzer W, Bassetti S, et al. Early diagnosis of myocardial infarction with sensitive cardiac troponin assays. N Engl F Med 2009;361:858-67.

10. Christ M, Popp S, Pohlmann H, et al. Implementation of high sensitivity cardiac troponin T measurement in the emergency department. Am $\mathscr{f} \mathrm{Med}$ 2010;123:1134-42.

11. Aldous SJ, Florkowski CM, Crozier IG, et al. Comparison of high sensitivity and contemporary troponin assays for the early detection of acute myocardial infarction in the emergency department [published erratum in Ann Clin Biochem. 2012;49 (Pt 2):208]. Ann Clin Biochem 2011;48(Pt 3):241-8.

12. Body R, Carley S, McDowell G, et al. Rapid exclusion of acute myocardial infarction in patients with undetectable troponin using a high-sensitivity assay. 7 Am Coll Cardiol 2011;58:1332-9.

13. Freund $\mathrm{Y}$, Chenevier-Gobeaux C, Bonnet $\mathrm{P}$, et al. High-sensitivity versus conventional troponin in the emergency department for the diagnosis of acute myocardial infarction. Crit Care 2011;15:R147.

14. Melki D, Lind S, Agewall S, et al. Diagnostic value of high sensitive troponin $\mathrm{T}$ in chest pain patients with no persistent ST-elevations. Scand Cardiovasc 7 2011;45:198-204.

15. Reiter M, Twerenbold R, Reichlin T, et al. Early diagnosis of acute myocardial infarction in the elderly using more sensitive cardiac troponin assays. Eur Heart 7 2011;32:1379-89.

16. Weber M, Bazzino O, Navarro Estrada JL, et al. Improved diagnostic and prognostic performance of a new high-sensitive troponin $\mathrm{T}$ assay in patients with acute coronary syndrome. Am Heart 7 2011;162:81-8.

17. Aldous SJ, Richards M, Cullen L, et al. Diagnostic and prognostic utility of early measurement with high-sensitivity troponin $\mathrm{T}$ assay in patients presenting with chest pain. CMA7 2012;184:E260-8.

18. Moher D, Liberati A, Tetzlaff J, et al; PRISMA Group. Preferred reporting items for systematic reviews and meta-analyses: the PRISMA statement. BMF 2009;339:b2535.

19. Higgins JP, Thompson SG. Quantifying heterogeneity in a meta-analysis. Stat Med 2002;21:1539-58

20. Higgins JP, Thompson SG, Deeks JJ, et al. Measuring inconsistency in metaanalyses. BM7 2003;327:557-60.

21. Reitsma JB, Glas AS, Rutjes AW, et al. Bivariate analysis of sensitivity and specificity produces informative summary measures in diagnostic reviews. $f$ Clin Epidemiol 2005;58:982-90.

22. Kiewiet JJ, Leeuwenburgh MM, Bipat S, et al. A systematic review and metaanalysis of diagnostic performance of imaging in acute cholecystitis. Radiology 2012;264:708-20.

23. Bhardwaj A, Truong QA, Peacock WF, et al. A multicenter comparison of established and emerging cardiac biomarkers for the diagnostic evaluation of chest pain in the emergency department. Am Heart 7. 2011 Aug;162:276282.e1.

24. Keller T, Zeller T, Peetz D, et al. Sensitive troponin I assay in early diagnosis of acute myocardial infarction. N Engl F Med 2009;361:868-77.

25. Thygesen K, Alpert JS, White HD. Universal definition of myocardial infarction. Eur Heart 7 2007;28:2525-38

26. Chatterjee S, Kim J, Dahhan A, et al. Use of high-sensitivity troponin assays predicts mortality in patients with normal conventional troponin assays on admission - insights from a meta-analysis. Clin Cardiol 2013;36:649-53.

28. Reichlin T, Irfan A, Twerenbold R, et al. Utility of absolute and relative changes in cardiac troponin concentrations in the early diagnosis of acute myocardial infarction. Circulation 2011;124:136-45.

29. Irfan A, Reichlin T, Twerenbold R, et al. Early diagnosis of myocardial infarction using absolute and relative changes in cardiac troponin concentrations. Am 7 Med. 2013;126:781-788.e2.

30. Reichlin T, Schindler C, Drexler B, et al. One-hour rule-out and rule-in of acute myocardial infarction using high-sensitivity cardiac troponin T. Arch Intern Med 2012;172:1211-8.

Affiliations: Department of Cardiology (Al-Saleh, Alazzoni, Jolly), Hamilton Health Sciences, McMaster University, Hamilton, Ont.; Department of Internal Medicine (Shalash), McMaster University, Hamilton, Ont.; Department of Clinical Epidemiology and Biostatistics (Ye, Mbuagbaw, Thabane), McMaster University, Hamilton, Ont.; Biostatistics Unit (Ye, Mbuagbaw), St Joseph's Healthcare, Hamilton, Ont.; Centre for Development of Best Practices in Health (Mbuagbaw), Yaoundé Central Hospital, Yaoundé, Cameroon; Departments of Anesthesia and Pediatrics (Thabane), McMaster University, Hamilton, Ont.; Population Health Research Institute (Thabane, Jolly), Hamilton Health Sciences, Hamilton, Ont.

Competing interests: None declared.

Contributors: All authors contributed substantially to the conception and design of the study and acquisition, analysis and interpretation of data. They all gave final approval of the version to be published and agreed to act as guarantors of the work.

Supplemental information: For the reviewer comments and the original submission of this manuscript, please see www.cmajopen.ca/content/2/3 /E199/suppl/DC1 